\title{
Physico-chemical changes during growth and development of papaya fruit. I: Physical changes
}

\author{
Adil El-Tayeb Shattir and Abu-Bakr Ali Abu-Goukh \\ Department of Horticulture, Faculty of Agriculture, University of Khartoum, Shambat, 13314, \\ Sudan \\ Corresponding author: Abu-Bakr Ali Abu-Goukh, phone number +249-912148700,
}

\begin{abstract}
Physical changes during growth and development of female and hermaphrodite fruits of 'Ekostika I', 'Ekostika II' and 'Baladi' papaya fruits were studied. The fruits of both types of the three cultivars followed typical simple sigmoid curves. Fruit fresh weight and volume progressively increased up to physiological maturity (120 days after anthesis, DAA) and remained constant afterwards. The female fruits of the three cultivars were shorter and wider and with higher fresh weight and volume at maturity, compared to hermaphrodite fruits. Respiration curves of both fruit types of the three papaya cultivars exhibited a typical climacteric pattern. Respiration rate progressively declined to a minimum value at physiological maturity (120 DAA) and then increased in a climacteric pattern with peak of respiration at 140 DAA. Fruit flesh firmness slightly decreased up the physiological maturity and then sharply declined in a similar manner. Most of that decline occurred during the ripening phase (125-145 DAA). Papaya fruits should be harvested shortly (5-10 days) after physiological maturity, where the fruit attains maximum size and weight, it is still firm and climacteric rise phase has just started.
\end{abstract}

Keywords: Papaya fruit, physical changes, growth and development.

\section{INTRODUCTION}

Papaya (Carica papaya L.) is an important and widely distributed fruit crop and is commercially grown in all tropical and many sub-tropical regions (Nakasone and Paull, 1998). It is usually dioecious with separate male and female trees; however, hermaphrodite (bisexual) cultivars are also occur (Salunkhe and Desai, 1984). Its annual world production amounts to $7,207,534$ metric tons, produced in 54 countries, on an area of about 378,000 hectares (FAO, 2007). The demand for fresh papaya fruit is increasing, due to its nutritional, medicinal and industrial value (Nakasone and Paull, 1998).

In Sudan, papaya fruit has shown an increasing trend in popularity among consumers and now it is grown in the Southern, Blue Nile and Sennar states. Although Sudan has great potential to produce high quality papayas and to export them to other countries, its marketability is still limited to local markets. This is due to the delicate nature of the fruit, limited know-how, poor handling practices, and inadequate transportation and storage facilities.

Harvesting papayas at proper level of maturity is essential for good quality produce. Over-maturity or under-maturity affects the quality adversely. Papaya fruits are generally picked when they exhibit a slight overall loss of green color, with some hint of yellow color at the blossom end. For long distance shipments the fruits are harvested at color-break stage (Kader et al, 2002). It is difficult to distinguish immature-green from mature-green fruits. Immaturegreen fruits will not ripen after long-distance refrigerated transport. Many physical and chemical changes undergone by the developing fruit have been used as means of assigning the optimal picking dates for immediate consumptions or storage. None of these parameters are reliable individually for determining harvest maturity. It usually requires a combination of chemical and physical parameters, coupled with considerable experience (Salunkhe and Desai, 1984).

This study was carried out to evaluate the physical changes that occur during growth and development of papaya fruit to provide base-line information regarding the biochemistry of the developing fruit and to assist in determining harvest maturity of papayas.

\section{MATERIALS AND METHODS}

Experimental site and setup: The experiment was conducted at the Demonstration Farm of Faculty of Agriculture, University of Sennar $\left(44^{\circ} 12^{\prime} \mathrm{N}, 38^{\circ}\right.$ 
$\left.8^{\prime} \mathrm{E}\right)$, which lies in a semi arid zone with heavy clay soils. Two introduced papaya cultivars 'Ekostika I' and 'Ekostika II' released by Malaysian Agricultural Research Development Institute (MARDI) and a local 'Baladi' cultivar were used in the experiment. Seeds of the three cultivars were raised in the nursery for six weeks. The seedlings when reached $30 \mathrm{~cm}$ in length were transplanted in the field $3 \mathrm{~m}$ apart, in a randomized block design with four replications. All trees were subjected to similar cultural practices.

Experimental material: Twenty trees from each cultivar were selected randomly (10 female and 10 hermaphrodite) from each replicate. The fruits were tagged at time of anthesis. Physical changes were determined on 20 fruits picked randomly at the designated stage in both fruit types of the three cultivars. These parameters were determined every 15 days after anthesis (DAA) up to the physiological maturity and then at 5-day intervals till the full-ripe stage.

Parameters studied: Average fruit weight was determined by an electrical balance and was expressed in grams. Fruit volume was estimated by water displacement and expressed in cubic centimeters. Fruit length and width were measured by varnier caliber (Whiter-Grew Model) and were expressed in centimeters. Respiration rate was determined in a flowing system by total absorption method and expressed in $\mathrm{mg} \mathrm{CO}_{2}$ per $\mathrm{kg}-\mathrm{hr}$ (Mohamed-Nour and Abu-Goukh, 2010). Fruit flesh firmness was determined by Magness and Taylor firmness tester (D.Ballauf Meg Co.) equipped with an $8 \mathrm{~mm}$-diameter plunger tip. Two readings were taken from opposite sides of each fruit after the peel was removed and was expressed in $\mathrm{kg}$ per $\mathrm{cm}^{2}$.

Statistical analysis: Analysis of variance (Gomez and Gomez, 1984), followed by Fisher's protected LSD test with a significant level of $\mathrm{P} \leq 0.05$ were performed on the data.

\section{RESULTS AND DISCUSSION}

Changes in fruit fresh weight: Papaya fruits of both fruit types in the three cultivars followed typical simple sigmoid curves. The fresh weight progressively increased with advancement in growth up to the physiological maturity (120 DAA), where the weight remained constant (Fig 1). Qiu et al. (1995) reported that the growth rate of papaya fruit proceeded at a slow rate up to 60 days post anthesis and sharply increased up to 100 days post anthesis. Similar results were reported in mango
(Abu-Goukh et al., 2005), date (Abd El-Rahman, 1974) and citrus (Ting and Attaway, 1971). The female fruit of the three cultivars had higher fresh weight at maturity of 1049,842 and $791 \mathrm{~g}$ for 'Baladi', 'Ekostika II' and 'Ekostika l', compared to the hermaphrodite fruits of 958,760 and $741 \mathrm{~g}$ for the three cultivars, respectively. The increase in fresh weight from 15 DAA to physiological maturity (120 DAA) was 5.3-, 7.1- and 7.2- folds in the female fruits and 5.2-, 8.1- and 9.0- folds in the hermaphrodite fruits in 'Baladi', 'Ekostika II' and 'Ekostika l' cultivars, respectively, (Fig. 1). Qiu et al. (1995) reported that papaya fruit mass had increased from $44 \mathrm{~g}, 40$ DAA to about $636 \mathrm{~g}, 140$ DAA. The variation in fruit weight of the different cultivars and fruit type could be genetically. Similar variation was reported during growth and development of the three mango cultivars (AbuGoukh et al., 2005).

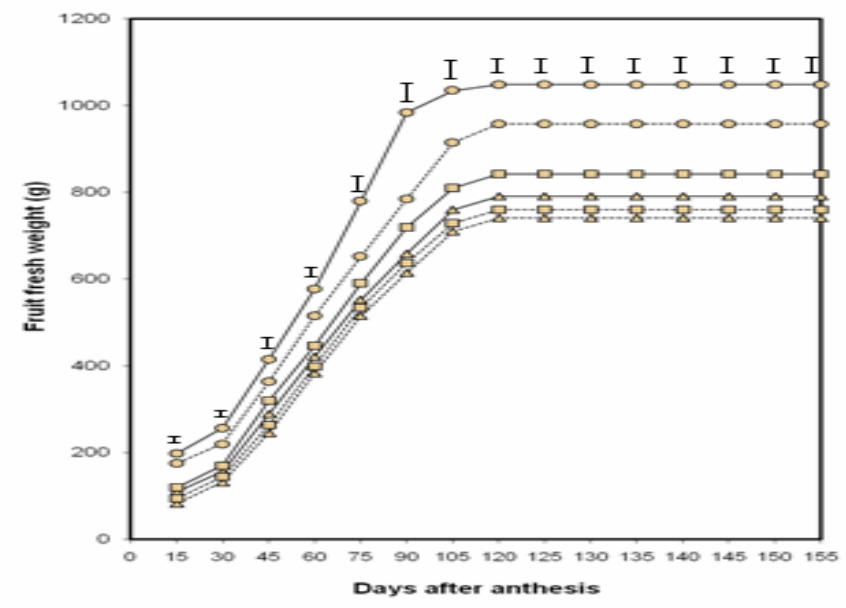

Fig. 1: Changes in fruit fresh weight during growth and development of female (__ ) and ermaphrodite $($........ ) fruits of 'Baladi' ( o ), 'Ekostika I' ( $\Delta$ ) and 'Ekostika II' ( $\left.{ }^{\prime}\right)$ papaya cultivars. Vertical bars represent LSD ( $5 \%$ ).

Changes in fruit volume: Changes in fruit volume during growth and development of both fruit types of the three papaya cultivars followed the same pattern of fruit fresh weight. Female fruits were larger at maturity of 962, 734 and $712 \mathrm{~cm}^{3}$ for 'Baladi', 'Ekostika II' and 'Ekostika I', compared to hermaphrodite fruits of 895,684 and $662 \mathrm{~cm}^{3}$ for the three cultivars, respectively (Fig. 2). The increase in fruit volume from 15 DAA to full maturity was 5.4-, 6.4- and 7.1- folds in the female fruits and 5.6-, 8.2and 9.9- folds in the hermaphrodite fruits of 'Baladi', 
'Ekostika II' and 'Ekostika I', respectively (Fig. 2). Similar patterns were reported for mango (AbuGoukh et al., 2005), date (Abd El-Rahman, 1974) and citrus fruits (Ting and Attaway, 1971).

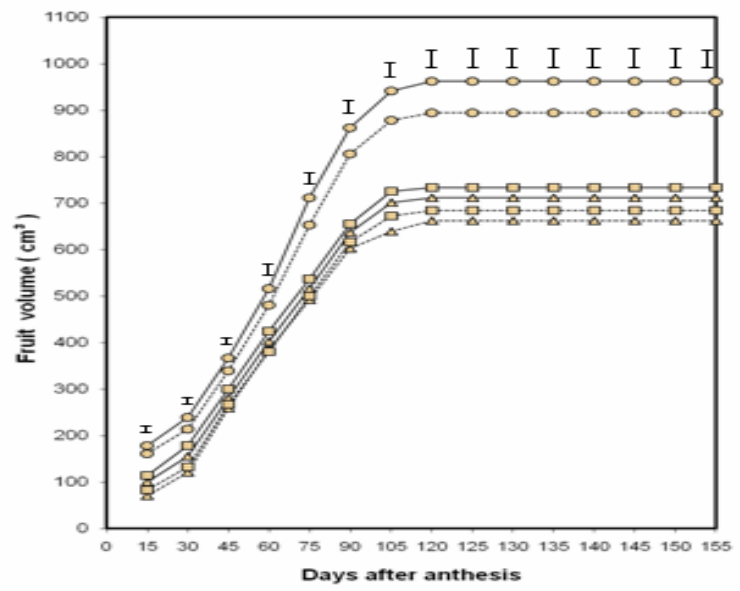

Fig. 2: Changes in fruit volume during growth and development of female ( $)$ and hermaphrodite ( ........) fruits of 'Baladi' ( o ), 'Ekostika I' $(\Delta)$ and 'Ekostika II' $(\square)$ papaya cultivars. Vertical bars represent LSD ( $5 \%$ ).

Changes in respiration rate: The respiration curves of both fruit types of the three papaya cultivars exhibited a typical climacteric pattern (Fig. 3). Respiration rate progressively declined from 15 DAA to a minimum value at physiological maturity $(120$ DAA) and then increased in a climacteric pattern with peak of respiration at 140 DAA (Fig. 3). Similar pattern was reported in papaya (Selvaraj et al., 1982), mango (Abu-Goukh et al., 2005; Lakshaminarayana et al., 1970), banana (Munasque and Mendoza, 1991) and guava (Akamine and Goo, 1979). Respiration rate was lowest in 'Baladi' cultivar, compared to 'Ekostika I', and 'Ekostika II' at all stages of growth and development of the fruit (Fig. 3). The differences were minor between 'Ekostika I' and 'Ekostika II' and between the female and hermaphrodite fruits within cultivars. Respiration rate is an excellent indicator for metabolic activity of the tissues, and thus is a useful guide for the potential storage life of fresh fruits and vegetables (Wills et al., 1998). Respiration rate is inversely proportional to shelf-life of the product, the lower rate the longer shelf-life (Day, 1993). Fruits of 'Baladi' cultivar with the lowest respiration rate (Fig. 3) and the highest flesh firmness (Fig. 4) at all stages of development, could have a longer shelflife, compared to the other two introduced cultivars.

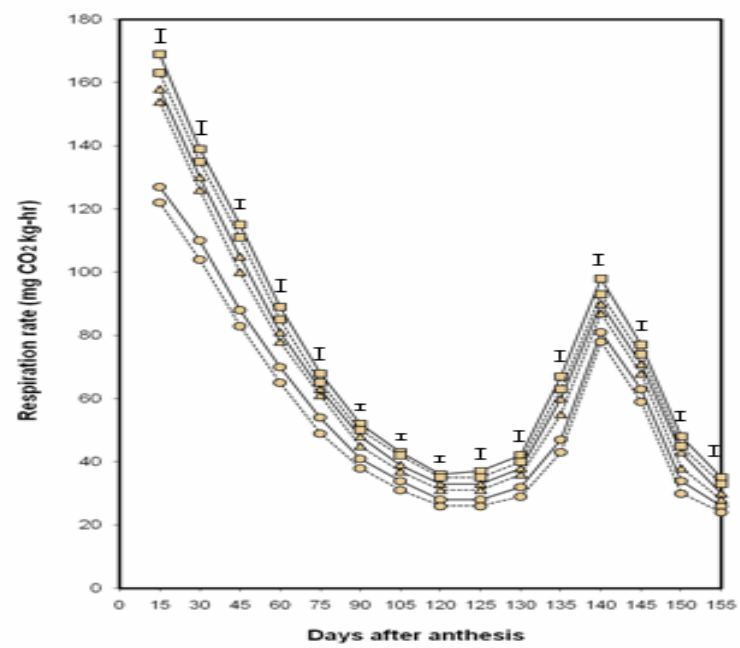

Fig. 3: Changes in respiration rate during growth and development of female $(\ldots)$ and hermaphrodite ( ........ ) fruits of 'Baladi' ( o ), 'Ekostika I' $(\Delta)$ and 'Ekostika II' ( $(\square)$ papaya cultivars. Vertical bars represent LSD ( $5 \%$ ).

Changes in fruit flesh firmness: Fruit flesh firmness of both fruit types of the three cultivars slightly decreased up to physiological maturity (120 DAA) and then sharply declined in a similar manner (Fig. 4). Most of that decline occurred during the ripening phase (125- $145 \mathrm{DAA})$. The drop in fruit flesh firmness from the mature stage (120 DAA) to the over-ripe stage (155 DAA) was 6.4-, 7.4- and 8.7-folds in fruits of 'Baladi', 'Ekostika l' and 'Ekostika II' cultivars, respectively, (Fig. 4). Similar results were reported during growth and development of mango (Abu-Goukh et al., 2005), guava (Rodriguez et al., 1971) and date (Coggins and Knapp, 1969) and during ripening of mango (Abu-Sarra and Abu-Goukh, 1992; Mohamed and Abu-Goukh et al., 2003), banana (Abu-Goukh et al., 1995; Osman and Abu-Goukh, 2008), guava (Bashir and Abu- Goukh, 2003) and tomato (Ahmed and Abu-Goukh, 2003). The decrease in fruit flesh firmness reflects chemical and physical changes in cell walls. It is associated with the action of the hydrolytic enzymes on the cell wall in mango (AbuSarra and Abu-Goukh, 1992), guava (Abu-Goukh and Bashir, 2003) and tomato (Ali and Abu-Goukh, 2005). The progressive loss of firmness with ripening is the result of gradual solublization of protopectin in the cell wall to form soluble pectins and other products (Ali and Abu-Goukh, 2005). 
Agric. Biol. J. N. Am., 2010, 1(5): 866-870

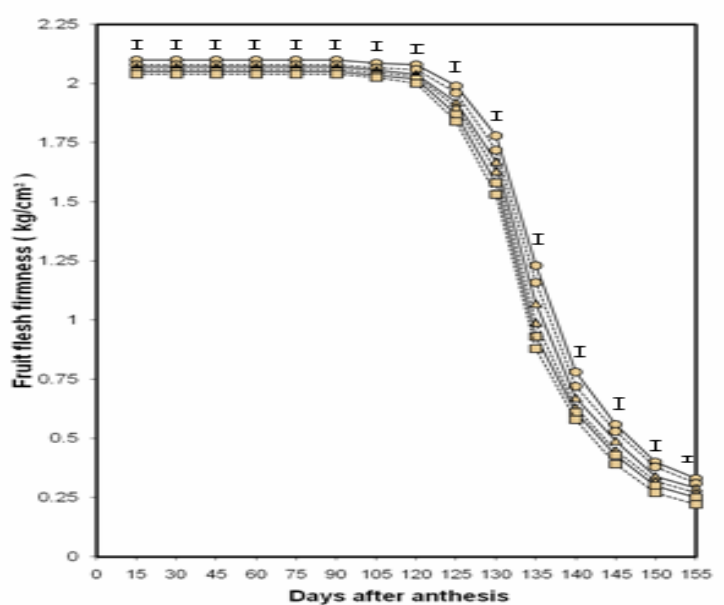

Fig. 4: Changes in fruit flesh firmness during growth and development of female $\left(\_\right)$and hermaphrodite ( ........ ) fruits of 'Baladi' ( o ), 'Ekostika I' $(\Delta)$ and 'Ekostika II' ( $\square$ ) papaya cultivars. Vertical bars represent LSD ( $5 \%)$.

Changes in fruit size: Fruit length and width of both fruits type in the three cultivars increased as growth advanced up to physiological maturity stage (120 DAA), and then remained constant (Figs. $5 \& 6$ ). The female fruits were shorter and wider, compared to the hermaphrodite fruits. The length of the mature female fruits was 13.2 to $14.8 \mathrm{~cm}$, while the length of the mature hermaphrodite fruits was 16.1 to $17.8 \mathrm{~cm}$ (Fig.5). At physiological maturity, the hermaphrodite fruits were $20.3 \%, 18.0 \%$ and $22.0 \%$ longer than the female fruits of 'Baladi', 'Ekostika II' and 'Ekostika I' cultivars, respectively, (Fig. 5). The width of the mature female fruits was 13.0, 12.4, and 12.0 cm for 'Baladi', 'Ekostika II' and 'Ekostika I' cultivars, respectively, (Fig. 6). It was $15.4 \%, 13.7 \%$ and $12.5 \%$ less in the mature hermaphrodite fruits, compared to the female fruit of the three cultivars, respectively. It was reported that papaya fruit shape vary depending on cultivar and fruit type. Fruits from female flowers are oblong to nearly spherical, while fruits from hermaphrodite flowers are pear-shaped, cylindrical or grooved (Purseglove, 1985).

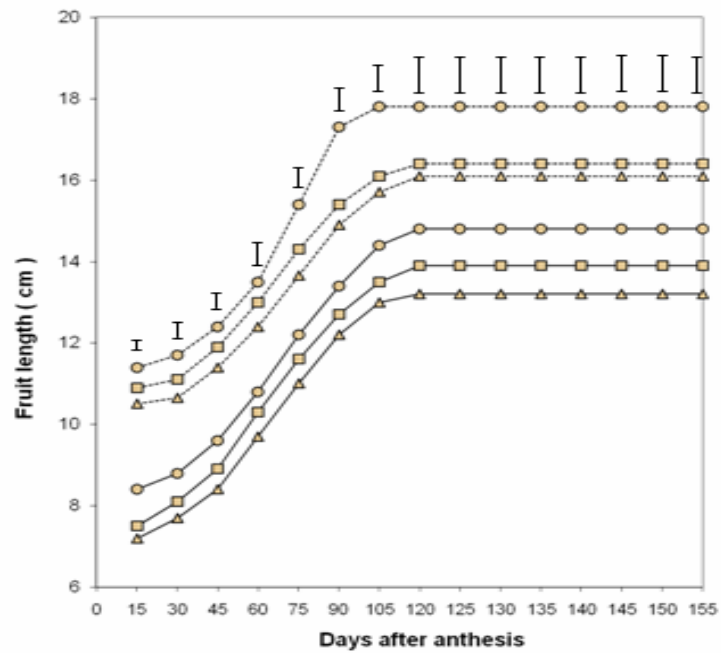

Fig. 5: Changes in fruit length during growth and development of female ( $)$ and hermaphrodite ( ........ ) fruits of 'Baladi' ( o ), 'Ekostika I' $(\Delta)$ and 'Ekostika II' ( $(\square)$ papaya cultivars. Vertical bars represent LSD ( $5 \%)$.

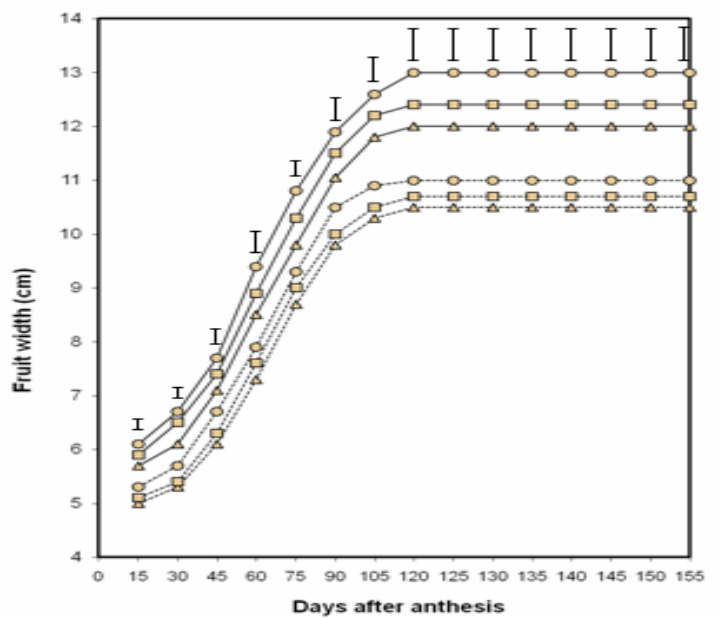

Fig. 6: Changes in fruit width during growth and development of female ( $\_$) and hermaphrodite ( ....... ) fruits of 'Baladi' ( o ), 'Ekostika I' $(\Delta)$ and 'Ekostika Il' ( $\square$ ) papaya cultivars. Vertical bars represent LSD ( $5 \%$ ).

\section{CONCLUSION}

Papaya fruits should be harvested shortly (5-10 days) after physiological maturity, where the fruit attains maximum size and weight, it is still firm and climacteric rise phase has just started. 


\section{REFERENCES}

Abd El-Rahman, M. H. (1974). Physiological and Physical Changes in Fruits of Some Date Varieties after Maturity. M.Sc. (Agriculture) Thesis, University of Cairo, Egypt.

Abu-Goukh, A. A. and Bashir, H. A. (2003). Changes in pectic enzymes and cellulase activity during guava fruit ripening. Journal of Food Chemistry, 83(2): 213218.

Abu-Goukh, A. A.; Ibrahim, K. E. and Yusuf, K. S. (1995). A comparative study of banana fruit quality and acceptability under different ripening conditions in Sudan. University of Khartoum Journal of Agricultural Sciences, 3 (2): 32-48.

Abu-Goukh, A. A.; Mohamed, H. E. and Garray, H. B. (2005). Physico-chemical changes during growth and development of mango fruit. University of Khartoum Journal of Agricultural Sciences, 13 (2); 179-191.

Abu-Sarra, A. F. and Abu-Goukh, A. A. (1992). Changes in pectinesterase, polygalacturonase and cellulase activity during mango fruit ripening. Journal of Horticultural Science, 67(4): 561-568.

Ahmed, I. H. and Abu-Goukh, A. A. (2003). Effect of maleic hydrazide and waxing on ripening and quality of tomato fruit. Gezira Journal of Agricultural Science, 1 (2): 59-72.

Akamine, E.K. and Goo, T. (1979). Respiration and ethylene production in fruits of species and cultivars of Psidium and species of Eugenia. Journal of the American Society for Horticultural Science, 104 (5): 632-636.

Ali, M. B. and Abu-Goukh, A. A. (2005). Changes in pectic substances and cell wall degrading enzymes during tomato fruit ripening. University of Khartoum Journal of Agricultural Sciences, 13 (2): 202-223.

Bashir, H. A. and Abu-Goukh, A. A. (2003). Compositional changes during guava fruit ripening. Journal of Food Chemistry, 80 (4): 557-563.

Coggins, C. W. Jr. and Knapp, J. C. F. (1969). Growth, development and softening of 'Deglet Nour' date fruits. Date Grower's Institute Annual Report. 46: 1114.

Day, B. (1993). Fruits and vegetables. In: Parry, R. T. (Ed.). Principles and Applications of MAP of Foods. Blackie Academic and Professional. New York, USA.

FAO (2007). Food and Agriculture Organization of the United Nations (FAO) Statistics, web site http:www.fao.org.

Gomez, K.W. and Gomez, A. A. (1984). Statistical Procedures for Agricultural Research. 2nd edition. John Wiley and Sons. Inc., New York, USA.

Kader, A. A.; Sommer, N. F. and Arpaia, M.L. (2002). Postharvest handling systems of tropical fruits. In: Kader,A.A. (Ed.). Postharvest Technology of Horticultural Crops. $3^{\text {rd }}$ Edition. Publication 3311, pp.
385-398. Division of Agriculture and Natural Resources, University of California, Oakland, California, USA.

Lakshminarayana, S.; Subhadra, N. V. and Subramanyam, H. (1970). Some aspects of developmental physiology of mango fruit. Journal of Horticultural Science, 45:133-142.

Mohamed, H. I. and Abu-Goukh, A. A. (2003). Effect of waxing and fungicide treatment on quality and shelflife of mango fruits. University of Khartoum Journal of Agricultural Sciences, 11 (3): 322-339.

Mohamed-Nour, I.A. and Abu-Goukh, A.A. (2010). Effect of ethrel in aqueous solution and ethylene released from ethrel on guava fruit ripening. Agric Biol $\mathrm{J}$ North Am, 1(3): 232-237.

Munasque. V. S. and Mendoza, D. J. (1991). Developmental physiology and ripening behavior of 'Senorita' banana fruit. ASEAE Food Journal, 5 (4): 152-157.

Nakasone, H. Y. and Paull, R. E. (1998). Tropical Fruits. CAB International, Oxon, UK, $443 \mathrm{pp}$.

Osman, H. E. and Abu-Goukh, A. A. (2008). Effect of polyethylene film lining and gibberellic acid on quality and shelf-life of banana fruits. University of Khartoum Journal of Agricultural Sciences, 16 (2): 241-260.

Purseglove, J. W. (1985). Tropical Crops: Dicotyledons. Fifth impression. Longmans Group Ltd. 718 pp.

Qiu, Y. X.; Nishina, M. S. and Paull, R. E. (1995). Papaya fruit growth, calcium uptake and fruit ripening. Journal of the American Society for Horticultural Science, 120: 246-253.

Rodriguez, R.; Agarwal, P. C. and Saha, N. K. (1971). Biochemical changes during development of 'Safeda', guava fruit. Indian Food Packers, 25 (1): 5-20.

Salunakhe, D. K. and Desai, B. B. (1984). Postharvest Biotechnology of Fruits. Vol. 2. Boca Raton, Florida. CRC. Press, Inc., USA, 148 pp.

Selvaraj, Y.; Pal, D. K.; Subramanyam, M.D. and Lyer, C. P. A. (1982). Changes in the chemical composition of four cultivars of papaya (Carica papaya L.) during growth and development. Journal of Horticultural Science, 57: 135-145.

Ting, S. V. and Attaway, J. A. (1971). Citrus fruits. In: Hulme, A. C. (Ed.). The Biochemistry of Fruits and their Products. New York; Academic Press Inc. Ltd. London. Vol. 2. 107-169.

Wills, R.H., McGlasson, B. Graham, D. and Joyce. D. (1998). Postharvest: An Introduction to the Physiology and Handling of Fruit, Vegetables and Ornamentals. $4^{\text {th }}$ Edition. CAB International, Willingford, Oxan, UK, $262 \mathrm{pp}$ 